\title{
Identification and expression analysis of c-type and g-type lysozymes genes after Aeromonas hydrophila infection in African catfish
}

\section{Identifikasi dan analisis ekspresi gen lisozim tipe-C dan tipe-G pada ikan lele dumbo setelah infeksi Aeromonas hydrophila}

\author{
Hasan Nasrullah ${ }^{1}$, Yanti Inneke Nababan ${ }^{1}$, Dwi Hany Yanti², Dian Hardiantho ${ }^{2}$, Sri \\ Nuryati $^{1}$, Muhammad Zairin Jr${ }^{1}$, Julie Ekasari ${ }^{1}$, Alimuddin Alimuddin ${ }^{{ }^{*}}$ \\ 'Department of Aquaculture, Faculty of Fisheries and Marine Sciences, IPB University, Bogor-16680, West-Java, \\ Indonesia. \\ ${ }^{2}$ National Centre for Freshwater Aquaculture, Sukabumi-43114, West-Java, Indonesia \\ *Corresponding author: Alimuddin Alimuddin@apps.ipb.ac.id \\ Tel/Fax: 0251-8622941
}

(Received April 12, 2019; Accepted June 26, 2019)

\begin{abstract}
Lysozymes play an important role in the first line of defense in fish and potentially used as an immunity status biomarker and immune responses evaluation in fish, which often found in two types, i.e. chicken-type and goosetype (c- and g-type, respectively). To recent, the information related to the sequences and the expression analysis of the c- and g-type lysozyme genes in African catfish is still limited. In the present study, we report a partial cloning and mRNA expression analysis of c-type and g-type lysozymes in African catfish Clarias gariepinus. We have successfully cloned and partially identify the c-type, and g-type lysozyme genes of $C$. gariepinus, which consist of 594 and 560 of coding sequences, respectively. Catalytic and other conserved residues were identified by multiple sequences alignment and they showed high similarity with other teleost fish species. mRNA levels of the genes were analyzed by using qPCR method and their expressions in the spleen, liver, and head kidney were rapidly modulated after Aeromonas hydrophila injection, with different patterns were observed in each organ. These results confirmed that c- and g-type lysozymes played an important role in non-specific immunity against $A$. hydrophila infection. This study provided valuable information that can be used to understand the African catfish immune systems for better disease and stress management in $C$. gariepinus culture.
\end{abstract}

Keywords: lysozymes, gene identification, gene expression, bacterial infection, African catfish

\begin{abstract}
ABSTRAK
Lisozim berperan dalam sistem pertahanan dini pada ikan dan sangat potensial digunakan sebagai marka status imunitas dalam evaluasi respons imun. Lisozim umum ditemukan dalam dua tipe pada ikan: tipe-ayam (tipe-c) dan tipe-angsa (tipe-g). Informasi terkait sekuens gen dan ekspresi gen kedua tipe lisozim pada ikan lele dumbo sangat terbatas. Pada penelitian ini, kami melaporkan kloning gen secara parsial, dan analisis ekspresi gen dari kedua tipe lisozim pada ikan lele dumbo C. gariepinus. Sekuens parsial gen lisozim tipe-c dan tipe-g yang berhasil diidentifikasi adalah sepanjang 594 dan 560 pasang basa. Situs katalitik dan residu khas memiliki tingkat kesamaan yang tinggi dengan spesies ikan yang lain. Analisis mRNA dilakukan dengan metode quantitative PCR (qPCR). Ekspresi kedua gen di jaringan ginjal depan, limpa, dan hati dengan cepat terinduksi pasca infeksi bakteri $A$. hydrophila dengan pola yang berbeda. Hasil ini menunjukkan bahwa lisozim tipe-c dan tipe-g memiliki peran yang sangat penting dalam sistem imun ikan lele dumbo terhadap infeksi A. hydrophila. Penelitian ini menghasilkan informasi penting yang dapat digunakan untuk mempelajari sistem imun ikan lele dumbo dan sebagai acuan dalam penanganan dan manajemen penyakit pada budidaya ikan lele dumbo.
\end{abstract}

Kata kunci: lisozim, identifikasi gen, ekspresi gen, infeksi bakteri, ikan lele dumbo 


\section{INTRODUCTION}

African catfish Clarias gariepinus is an important aquaculture species in the world that mainly produced in African and Asian country, including Indonesia (Ekasari et al., 2016; Shoko et al., 2016; Dauda et al., 2018). C. gariepinus production has increased significantly through various system development and intensive fish culture practices (Ekasari et al., 2016; Fauji et $a l ., 2018)$, consequently exposes the cultured fish to common stressors including the deterioration of water quality and intensive handling. These stressors could bring about adverse effects on the fish health status and increase its susceptibility to disease infection (Cardinaud et al., 2014; Bardon-albaret \& Saillant, 2016; Yarahmadi et al., 2016). One of the most commonly occurred infection diseases in African catfish is motile aeromonad septicemia (MAS) caused by Aeromonas hydrophila infection. This Gramnegative bacterium has caused high mortality in some freshwater aquaculture species and induced serious epidemics of ulcerative disease leading to a heavy economic loss in C. gariepinus culture (Angka et al., 1995; Azis et al., 2015; Zhou et al., 2018).

As one of the fish bacterial defense components, lysozyme has crucial roles. This hydrolase enzyme catalyzes the hydrolysis of $\beta$ - $(1,4)$-glycosidic bond between the $\mathrm{N}$-acetyl glucosamine and $\mathrm{N}$-acetyl muramic acid in the peptidoglycan layer of bacterial cell walls and possess bacteriolytic activity against Grampositive and Gram-negative bacteria (Saurabh
\& Sahoo, 2008; Wang et al., 2016). Generally, among the vertebrate and teleost fish, lysozyme is mostly found in two forms, i.e. chicken-type $(c-L y z)$ and goose-type ( $g$-Lyz) (Callewaert \& Michiels, 2010; Callewaert et al., 2012; Zhang et al., 2018). The c- and g-type of lysozymes have been demonstrated to play important roles in the immune defense in many fish species, especially in protection against pathogenic bacterial infection (Liu et al., 2016; Wang et al., 2016; Di Falco et al., 2017; Gou et al., 2018).

Both lysozymes genes are important biomarker molecules in evaluating immune and stress status in C. gariepinus aquaculture. However, to our knowledge, no reports have been documented on the molecular identification of these genes in C. gariepinus species. Moreover, the expression pattern of lysozyme genes after A. hydrophila challenges treatment are not documented yet. In the present study, we cloned partial cDNA of c-type and g-type lysozymes and evaluated their in vivo mRNA gene expressions after A. hydrophila infection. This study provides new information related to the immune genes of $C$. gariepinus species, and thus will extend our knowledge and provide a better understanding in $C$. gariepinus immune system.

\section{MATERIAL AND METHODS}

\section{Primers design}

Primers for cDNA amplification were designed based on the conserved sequences in the corresponding genes of several teleost fish available at gene database (GenBank; http://

Table 1. Primer used in this study

\begin{tabular}{|c|c|c|c|}
\hline Name & Sequence $\left(5^{\prime}-3^{\prime}\right)$ & Temperature $\left({ }^{\circ} \mathrm{C}\right)$ & Application \\
\hline LysC-F & GCTAAACGGTATGATCGGTGTGA & \multirow{2}{*}{55} & Partial identification \\
\hline LysC-R & GCAGGAGATTTTACACCCGTT & & \multirow{3}{*}{ qPCR analysis } \\
\hline $\mathrm{qCgLC} \mathrm{F}$ & CGGTATGATCGGTGTGAGCTGG & \multirow{2}{*}{60} & \\
\hline qCgLC R & CGGTTCTGGGCGTTGGTATTGA & & \\
\hline 3'RACE Lc & AGTCGTACTTCAATACCAACGCCC & 60 & 3' RACE PCR \\
\hline LysG-F & GGCATTATATCCAGAGAGTC & \multirow{2}{*}{56.5} & \multirow[t]{2}{*}{ Partial identification } \\
\hline LysG-R & CGAGCAACCACATCATTGG & & \\
\hline $\mathrm{qCgLG} \mathrm{F}$ & CCTAACTGGCCCAAAGAGCA & \multirow[t]{3}{*}{60} & \multirow[t]{2}{*}{ qPCR analysis } \\
\hline qCgLG R & CCATACCCTCGTATGTGCGG & & \\
\hline 3'RACE Lg & GAGGGGAGCATGGAACAGTAAGG & & 3' RACE PCR \\
\hline $\operatorname{Oligo}(\mathrm{dT})_{18}$ & $\operatorname{NNNN}\left(\mathrm{T}_{18}\right)$ & 60 & 3' RACE PCR \\
\hline $\mathrm{Cg} \beta$ actinF & ACCGGAGTCCATCACAATACCAGT & \multirow{2}{*}{60} & \multirow[t]{2}{*}{ Internal control } \\
\hline $\mathrm{Cg} \beta$ actinR & GAGCTGCGTGTTGCCCCTGAG & & \\
\hline
\end{tabular}


www.ncbi.nlm.nih.gov/genbank). The size of amplification product was predicted using primer-BLAST program (www.ncbi.nlm.nih.gov/ tools/primer-blast). Melting temperature, dimers, and secondary structures were predicted using Oligo Analyzer 3.1 program (sg.idtdna.com/calc/ analyzer). $\beta$-actin gene was used as an internal control and for expression level normalization. Real-time PCR primers were designed based on the results of the cloned sequences after partial identification. All primers used in this study were summarized at Table 1.

\section{Total RNA extraction and cDNA synthesis}

Total RNA was extracted from the liver and head kidney using GENEzol ${ }^{\mathrm{TM}}$ reagent (Genaid, Taiwan) following the manufacturer's instruction. The concentration of total RNA was measured using spectrophotometer at optical densities of 260 and $280 \mathrm{~nm}$, respectively. RNA purification and the first strand cDNA synthesis were carried out from $1 \mu \mathrm{g}$ of total RNA using RevertraAce ${ }^{\circledR}$ qPCR RT Mastermix with gDNA remover kit (Toyobo, Japan) according to the manufacturer's manual. RNA integrity was evaluated by gel agarose electrophoresis method and gDNA contamination was verified by PCR-amplification using intron-spanning primer for $\beta$-actin genes. The cDNA was diluted in nucleases free water and stored at $-20^{\circ} \mathrm{C}$ prior to use.

\section{Gene cloning}

Partial sequences of $c-L y z$ and $g-L y z$ were amplified by PCR method. PCR reactions were performed in a total volume of $30 \mu \mathrm{L}$, consisting of $15 \mu \mathrm{L}$ premix of MyTaq ${ }^{\mathrm{TM}}$ Red Mix (Bioline, $\mathrm{UK}), 1 \mu \mathrm{L}(10 \mu \mathrm{M})$ of each primer, $12 \mu \mathrm{L}$ nucleases free water, and $1 \mu \mathrm{L}(50 \mathrm{ng} / \mu \mathrm{L})$ of cDNA template from the fish liver. PCR thermal cycling programs were set as follow: $95^{\circ} \mathrm{C}$ for $3 \mathrm{~min} ; 35$ cycles of $95^{\circ} \mathrm{C}$ for $30 \mathrm{~s}$, each primer annealing temperature for $30 \mathrm{~s}$ and $72^{\circ} \mathrm{C}$ for 30 second; and final extension at $72^{\circ} \mathrm{C}$ for $5 \mathrm{~min}$. PCR products were separated on $1.5 \%$ agarose gel and purified using Wizard ${ }^{\circledR}$ SV Gel and PCR Clean-Up (Promega, USA) following kit protocol. Purified PCR products concentration was measured then ligated into pTA2 vector using Target Clone -Plus- (Toyobo, Japan). Ligated vector was transformed into Escherichia coli DH5 $\alpha$ competent cells. Positive colonies were taken and verified by PCR. Plasmid isolation from positive colonies were performed using Illustra ${ }^{\mathrm{TM}}$ Plasmid Mini Kit (GE Healthcare, USA). Plasmid were amplified using universal $\mathrm{T} 7$ promotor and M13 reverse primers for sequencing. To obtain the 3'Untranslated Region (3'UTR) of the genes, the 3'RACE (rapid amplification of cDNA ends) was conducted using the 3'RACE primer that designed based on the cloned sequences.

\section{Sequence reading and bioinformatic analysis}

PCR product for sequencing was purified using ExoSAP-IT (GE Healthcare, USA). PCR labelling conducted using BigDye ${ }^{\circledR}$ Terminator v3. Cycle Sequencing Kit (Applied Biosystems, USA) and purified using BigDyeXTerminator ${ }^{\mathrm{TM}}$ Purification Kit (Applied Biosystems, USA). Sequence reading was performed using 3500 Genetic Analyzer machine (Applied Biosystems, USA). All sequencing preparation and reading was conducted in the Main Centre for Freshwater Aquaculture, Sukabumi, West-Java, Indonesia. Nucleotide sequence and its predicted amino acid residues were compared to other teleost and species using BLASTN and BLASTX program (blast.ncbi.nlm.nih.gov). Conserved domain of the genes was predicted using Conserved Domain Database (https://www.ncbi.nlm.nih.gov/cdd/) and SMART (http://smart.embl-heidelberg. de/) using the partial amino acid sequences. Phylogenetic tree was constructed using neighborjoining method with default settings and 1000x bootstraps on MEGAX software (https://www. megasoftware.net) based on the partial amino acid sequences of each genes.

\section{Bacterial infection}

Pathogenic A. hydrophila was obtained from the Laboratory of Fish Health Management, IPB University, Indonesia, which was isolated from naturally infected fish at a local fish farm. The isolate was characterized using biochemical test. A. hydrophila was suspended in PBS solution at a final concentration of $10^{7} \mathrm{CFU} / \mathrm{mL}$, which was determined according to $\mathrm{LD}_{50}$ test prior to the experiment. Ninety individuals $(60 \pm 8 \mathrm{~g})$ were acclimated at $28-29^{\circ} \mathrm{C}$ in 18 glass tanks (5 individuals/tank; $15 \mathrm{~L}$ ) for one week. Fish were fed twice daily (08.00 and 17.00) with a commercial feed. Feed and fecal wastes were removed daily. Before injection, the fish was anesthetized with $100 \mathrm{mg} / \mathrm{L}$ MS222. Forty-five fish was injected with $0.1 \mathrm{~mL}$ of $A$. hydrophila suspension intramuscularly as the treatment group, and forty-five other was injected by $0.1 \mathrm{~mL}$ PBS as a control group. Liver, head kidney, and spleen were collected from randomly selected fish at $0 \mathrm{~h}, 6$ h, 12 h, 24 h, 48 h, and 96 h post-infection (hpi; $\mathrm{n}=3$ ). Fish were deep-anesthetized with $200 \mathrm{mg} / \mathrm{L}$ MS222 for 2-3 min before tissues collection. 




Figure 1. Partial nucleotide sequence of C. gariepinus c-Lyz gene

\section{Gene expression and statistical analysis}

Real-time PCR (qPCR) was used to determine mRNA expression of $c-L y z$ and $g-L y z$ genes. The qPCR reaction was performed in a Rotor-Gene 6000 (Corbett, USA) machine. An aliquot of 20 $\mu \mathrm{L}$ of total volume reaction containing $10 \mu \mathrm{L} 2 \times$ SensiFAST SYBR ${ }^{\circledR}$ NO-ROX (Bioline, UK), 0.8 $\mu \mathrm{L}(10 \mu \mathrm{M})$ of each qPCR primer, $4 \mu \mathrm{L}$ of 10 ngcDNA from the tissues, and $4.4 \mu \mathrm{L}$ nucleases free water. The amplifying program was set at $95^{\circ} \mathrm{C}$ for $2 \mathrm{~min}$, and 40 cycles of $95^{\circ} \mathrm{C}$ for $10 \mathrm{~s}, 60^{\circ} \mathrm{C}$ for $15 \mathrm{~s}$, and $72^{\circ} \mathrm{C}$ for $15 \mathrm{~s}$. Melting curve analysis was conducted after amplification program to evaluate the primer specificity. Levels of all the genes were analyzed according to the $2^{-\triangle \triangle C T}$ method (Livak \& Schmittgen, 2001) after normalized with the $\beta$-actin gene. The fold change of expression levels after bacterial infection were compared to the expression of the control group at the same time point. All expression data were presented as average \pm SD. All statistical analyses were conducted in the SPSS v.17 software (SPSS Inc, USA).

\section{RESULTS}

\section{Gene identification}

The genes of $c$-Lyz and $g$-Lyz of C. gariepinus were successfully cloned and partially identified, which consisted of 594 and 560 of coding 


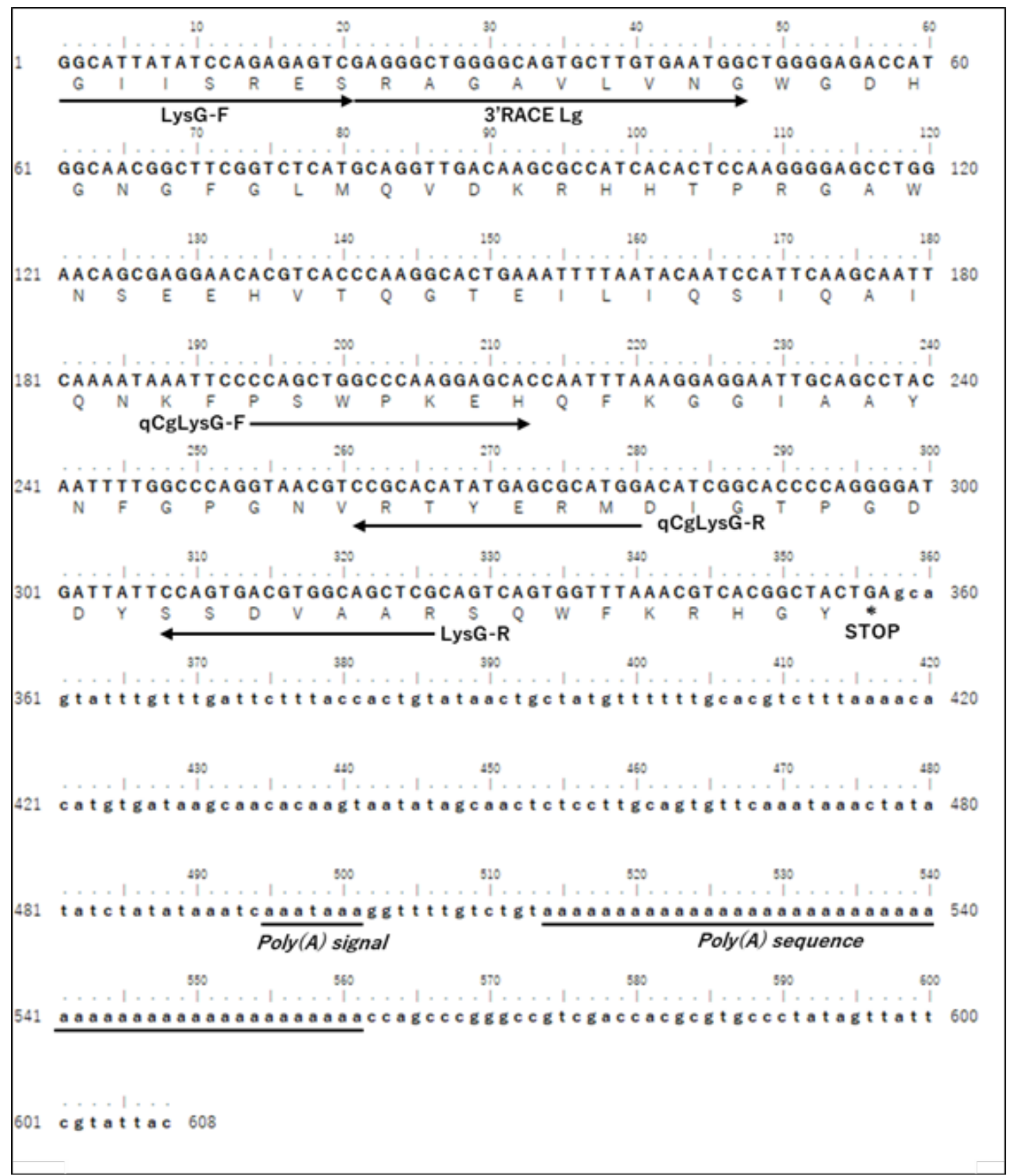

Figure 2. The partial nucleotide sequence of $C$. gariepinus g-Lyz gene

sequences, respectively. The corresponding mRNA sequences have been submitted to the GenBank under accession number of MK112877 $(c-L y z)$ and MH341528 ( $g-L y z)$, respectively. The sequence features were presented in the Figure 1 and 2. Primers sequences were also marked within the gene sequences. The 3'UTR region of both gene were identified, including the AT-rich region and the poly-A sequence.

The translated amino acid residues for all the genes are showing high similarity with other teleost fish (Figure 3). All identified sequence belongf to lysozyme protein domain. Cysteine residues and catalytic sites of the enzymes, and the signature sequence of both lysozymes were also identified. The phylogenetic tree showed that all the identified genes were clustered in one clade with other fish species and closely related to other catfish species. Both $c-L y z$ and $g-L y z$ were separated from other group such as mammals, avian, and reptile (Figure 4).

\section{Bacterial infection experiment}

The mRNA levels of $c-L y z$ and $g-L y z$ were modulated after $A$. hydrophila injection with different patterns was observed for each organ (Figure 5). The $c$-Lyz expression was significantly modulated at 6 hpi $(\mathrm{P}<0.01$ or $\mathrm{P}<0.05)$ in all 


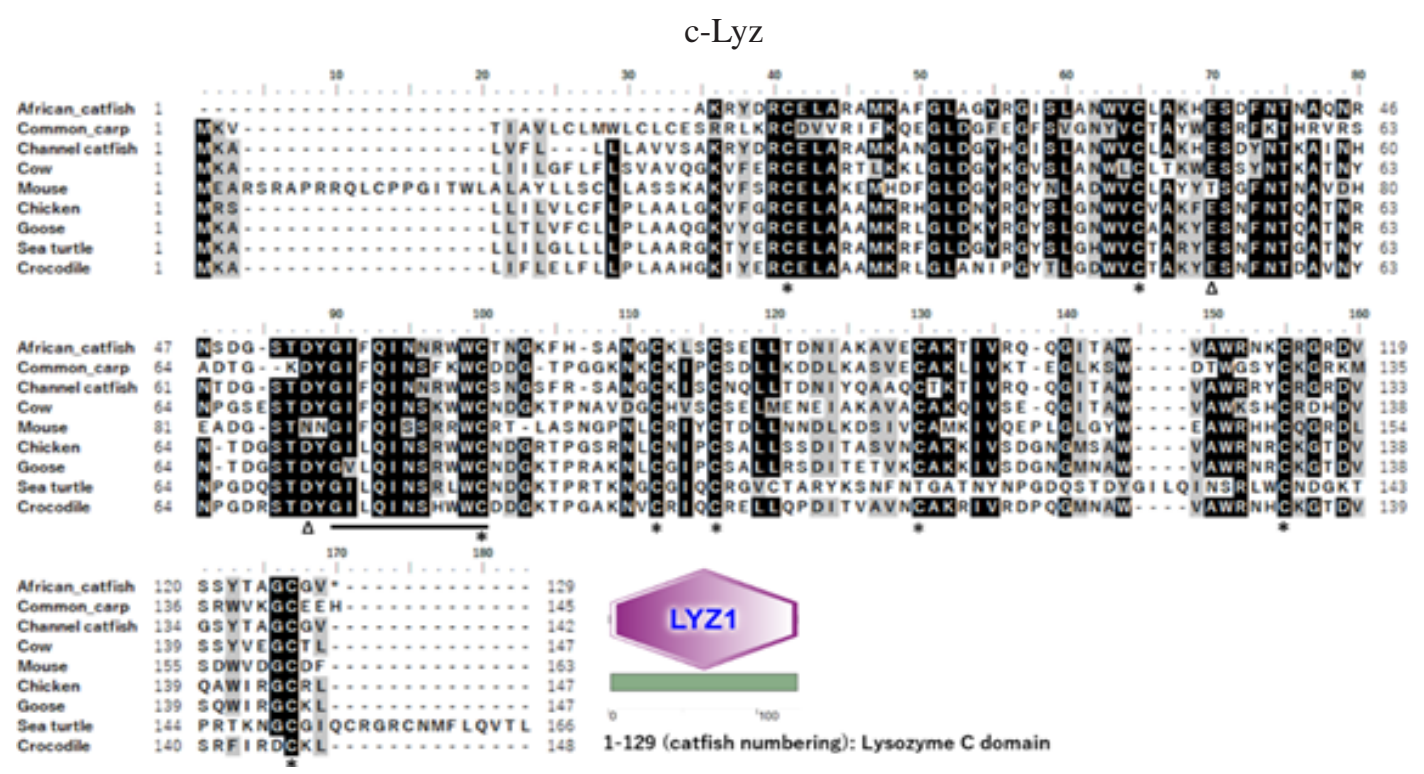

g-Lyz

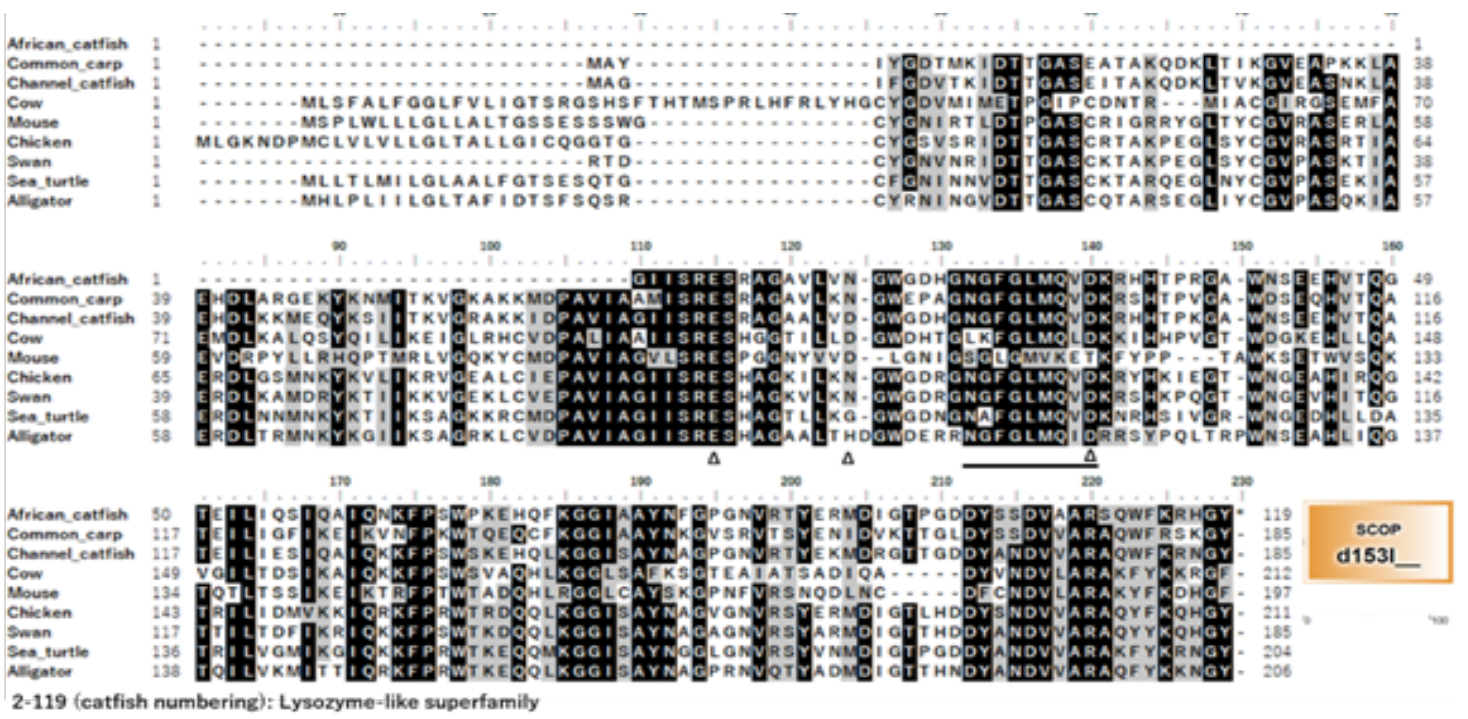

Figures 3. Multiple alignment of amino acid sequence of $C$. gariepinus lysozymes gene with other species. Identical residues are highlighted in black, grey shadows indicate similar residues within $75 \%$ similarity threshold, dashes (_) indicate gaps in the aligned amino acid sequences, asterisks * indicate cysteine residues, arrow heads $\Delta$ indicate catalytic sites. Signature sequences of the both lysozymes are underlined.
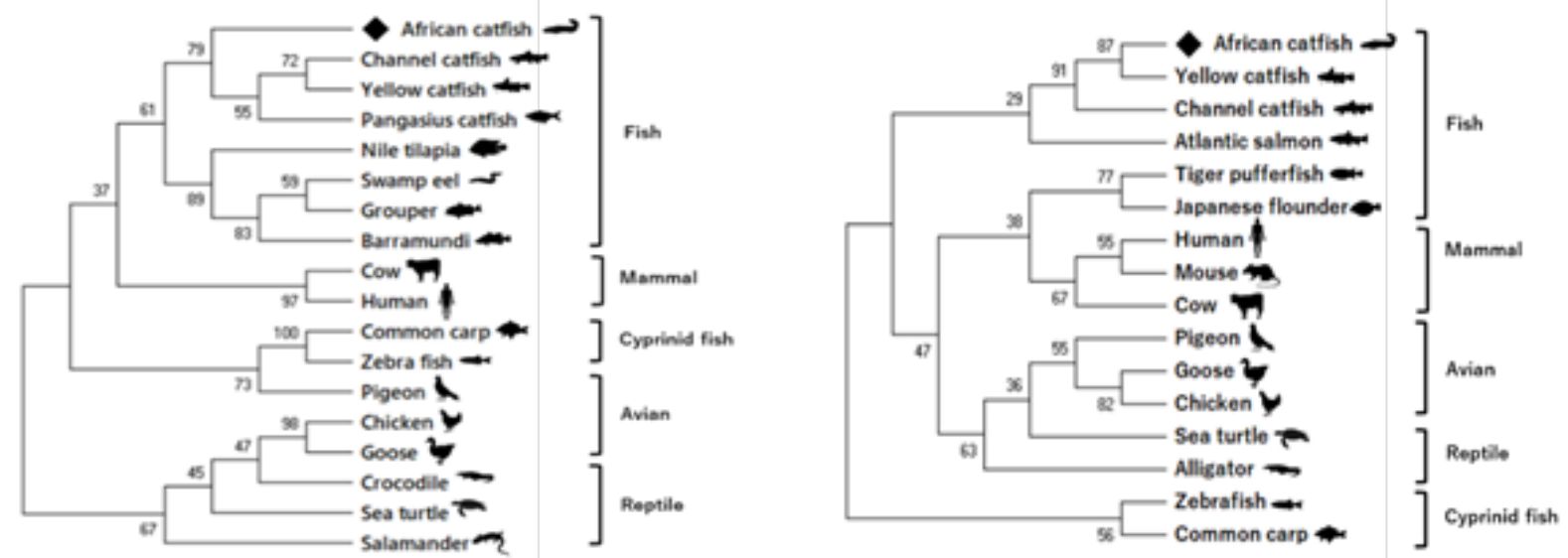

Figure 4. Phylogenetic tree of c-type and g-type lysozyme of African catfish and other species. Phylogenetic tree was constructed using neighbour-joining method with $1000 \times$ bootstrap. 

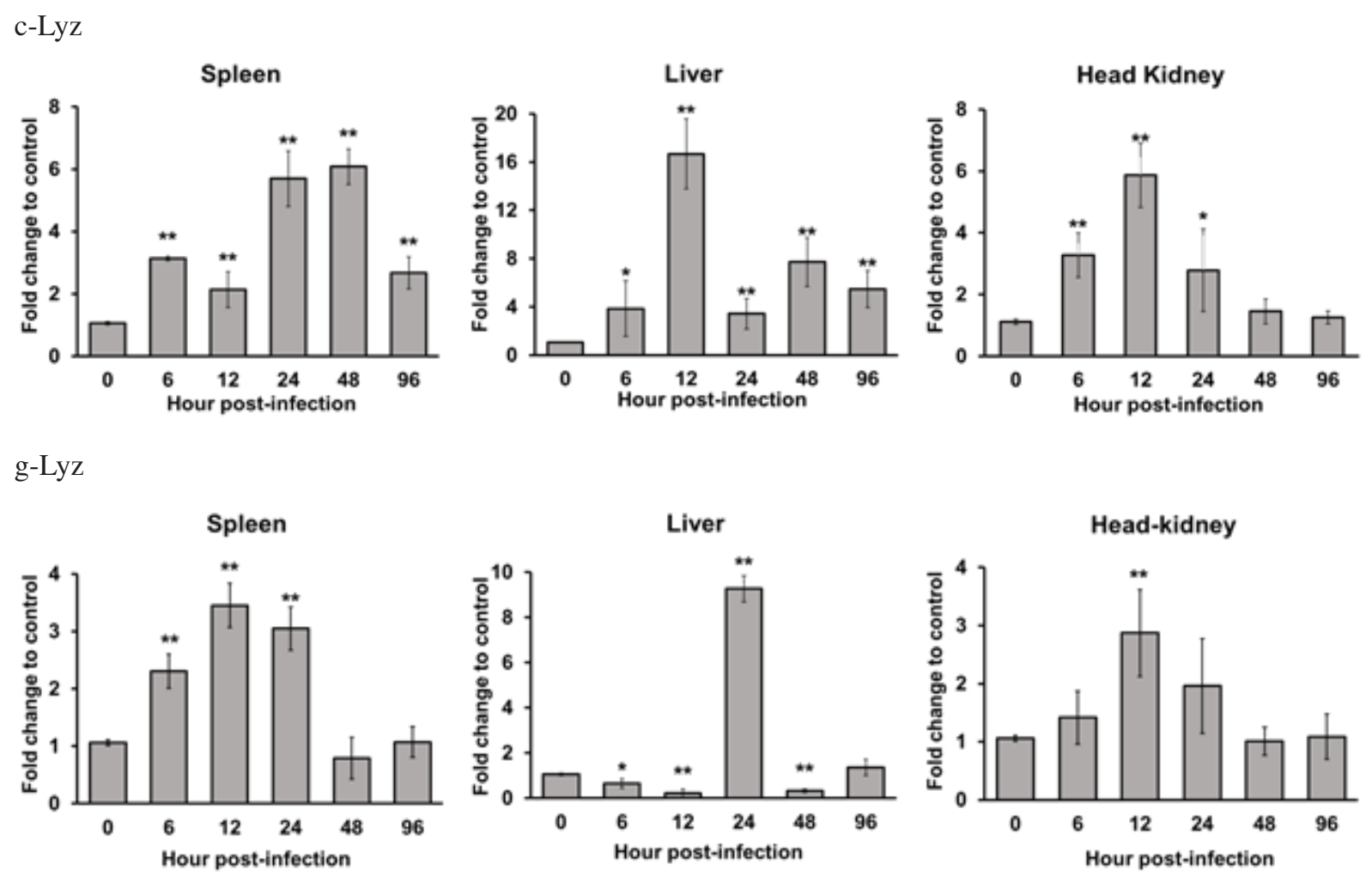

Figure 5. The expression pattern of lysozyme genes transcripts in the spleen, liver, and head kidney of $C$. gariepinus following injection with pathogenic A. hydrophila. Expression ratio was normalized to $\beta$-actin. Asterisks symbols indicate the significance in difference to the fish mRNA transcripts before the infection $(*=p<0.05 ; * *=p<0.01)$. Data was presented as mean $\pm \mathrm{SD}(\mathrm{n}=3)$ and showed as fold change relative to the control group at the same time points.
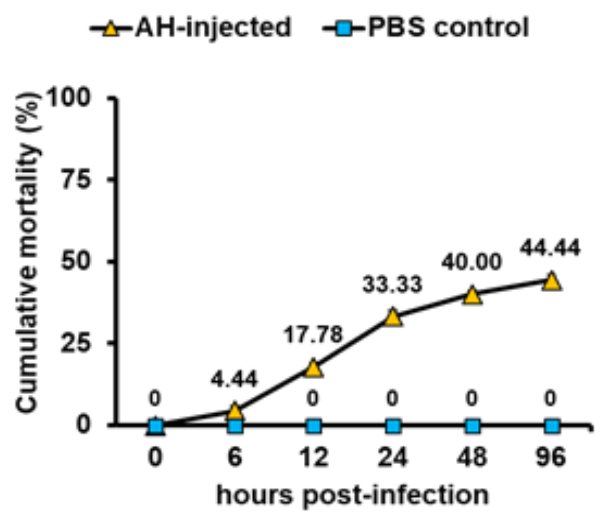

Figure 6. Cumulative mortality of C. gariepinus after subjected to $107 \mathrm{CFU} / \mathrm{mL}$ A. hydrophila injection

tissues, and maintained its significant expression until 96 hpi in spleen and liver $(\mathrm{P}<0.01$ or $\mathrm{P}<0.05)$. Its expression in the head kidney was decreased to basal level at 48 and $96 \mathrm{hpi}$. The $g$-Lyz expression patterns in the spleen and head kidney were similar, it rapidly modulated at $6 \mathrm{hpi}$ and reached a significant peak at 12 hpi $(\mathrm{P}<0.01)$, then decreased to its basal levels at 48 and 96 hpi. In the liver, $g-L y z$ expression was downregulated at 6 and 12 hpi $(\mathrm{P}<0.05$ or $\mathrm{P}<0.01)$ and after 12 hpi the expression levels reached its peak $(\mathrm{P}<0.01)$, thereafter it was down regulated to its basal levels.
The fish cumulative mortality following injection with $A$. hydrophila was also observed and presented in Figure 6. For the first 24 hpi, fish mortality in the injected group was about $33.33 \%$. On the second day, fish cumulative mortality was $40 \%$ and became $44.44 \%$ at 96 hpi. No mortality was found at the control group during the experiment.

\section{DISCUSSION}

The innate immune system is a fundamental defense mechanism in fish and has some important roles in fish homeostasis and immune system 
(Magnadóttir, 2006). One of its components, viz. lysozymes, act as the first line of defense in fish and provide the initial resistance to pathogens within the first hour of infection (Saurabh \& Sahoo, 2008; Ye et al., 2010; Pridgeon et al., 2013; Zhang et al., 2018). The information related to the immunerelated genes of African catfish is still scarce, and accordingly the immune response evaluation based on the immune genes on mRNA levels after bacterial infection and stressors induction is still limited. The lack of research on African catfish immune system remains as a major constraint in understanding the development of immune system, vaccine development, immune-stimulant and culture system evaluation, and selection of bacterial resistant strains through marked assisted selection or selective breeding. Considering the current situation on $C$. gariepinus immune research, it is necessary to enhance its research especially regarding to immune-related genes identification and its expression evaluation after bacterial challenge.

The present study provides the sequence information and the mRNA levels evaluation of African catfish $c-L y z$ and $g-L y z$ genes after A. hydrophila infection. Based on the partial identification results, the amino acid residues of the genes were similar to the corresponding sequences in other teleost fishes (Figure 1). African catfish c-type and g-type lysozymes possessed two and three catalytic sites and showed homology with other fish species (Liu et al., 2016; Zhang et al., 2018). The signature sequences of $c-L y z$ and $g-L y z$ and the conserved cysteine residues was also found within the $C$. gariepinus sequences, which was also reported in most of the fish species (Buonocore et al., 2014; Wohlkönig et al., 2010). These results indicated that the cloned and identified genes are the lysozyme genes of African catfish. However, full-length characterization is still needed to extend our knowledge about the genes function in immune and stress responses of $C$. gariepinus.

Rapid induction was shown by all the genes in all examined tissues after bacterial infection with different patterns were observed in different organs tested in this study. This indicates that their important roles as immune components for early defense system against bacterial infection (Figure 5). Chicken type and goose type lysozyme have a relatively different patterns of induction in the liver. The $c-L y z$ expression was induced in the early time of infection while $g-L y z$ expression was decreased in the same time points in the liver. After $24 \mathrm{~h}$ they 'shifted' their expression. Such expression pattern also reported in the liver of Darby's sturgeon Acipenser dabryanus (Zhang et al., 2018) and channel catfish Ictalurus punctatus (Wang et al., 2013) after A. hydrophila and Edwardsiella ictaluri infection. This pattern was suggested as "collaborative" functions of the lysozymes after bacterial infection (Wang et al., 2013). Up-regulation of both lysozyme mRNA expressions after bacterial challenge also widely reported in teleost fish. In grass carp Ctenopharyngodon idella, g-type lysozyme expression was significantly up-regulated after $24 \mathrm{~h}, 72 \mathrm{~h}$ and 7 days in the liver, head kidney, and spleen after A. hydrophila injection, but only after $72 \mathrm{~h}$ in gill for c-type lysozyme (Ye et al., 2010). The c-type and g-type lysozyme of $I$. puncatatus were also significantly increased in the liver, spleen, and head-kidney after E. tarda injection (Wang et al., 2013). In general, after bacterial infection in C. gariepinus, c-Lyz mRNA expressions were induced higher than $g$-Lyz. This result suggest that both lysozymes may play a crucial role in the immunological responses of African catfish against $A$. hydrophila infection.

\section{CONCLUSION}

We have identified and cloned the partial cDNA of c-type lysozyme and g-type lysozyme from African catfish $C$. gariepinus. Their expression modulation in immune tissues after $A$. hydrophila injection marked their importance in host immune response against bacterial infection. This study provided valuable information that can be used to understand the African catfish immune systems and to provide better disease and stress management in $C$. gariepinus culture. However, further studies to fully-characterize the corresponding genes will extend our knowledge about its molecular function and mechanisms.

\section{ACKNOWLEDGEMENT}

This work was supported by the Ministry of Research and Higher Education, Republic of Indonesia [grant number: PMDSU 1098/IT3.11/ LT/2017].

\section{REFERENCES}

Angka SL, Lam TJ, Sin YM. 1995. Some virulence characteristics of Aeromonashydrophila in walking catfish (Clarias gariepinus). Aquaculture 130: 103-112. 
Azis, Alimuddin, Sukenda, Zairin M. 2015. MHC I molecular marker inheritance and first generation catfish Clarias sp. resistance against Aeromonas hydrophila infection. Pakistan Journal of Biotechnology 12: 131137.

Bardon-albaret A, Saillant EA. 2016. Effects of hypoxia and elevated ammonia concentration on the viability of red snapper embryos and early larvae. Aquaculture. 459: 148-155

Buonocore F, Randelli E, Trisolino P, Facchiano A, de Pascale D, Scapigliati G. 2014. Molecular characterization, gene structure and antibacterial activity of a g-type lysozyme from the European sea bass Dicentrarchus labrax L. Molecular Immunology 62: 10-18.

Callewaert L, Van Herreweghe JM, Vanderkelen L, Leysen S, Voet A, Michiels CW. 2012. Guards of the great wall: bacterial lysozyme inhibitors. Trends in Microbiology 20: 501510.

Callewaert L, Michiels CW. 2010. Lysozymes in the animal kingdom. Journal of Bioscience 35: 127-160.

Cardinaud M, Offret C, Huchette S, Moraga D, Paillard C. 2014. The impacts of handling and air exposure on immune parameters, gene expression, and susceptibility to vibriosis of European abalone Haliotis tuberculata. Fish and Shellfish Immunology 36: 1-8.

Dauda AB, Natrah I, Karim M, Kamarudin MS, Bichi A u H. 2018. African catfish aquaculture in Malaysia and Nigeria: status, trends and prospects. Fisheries and Aquaculture Journal 09: $1-5$

Ekasari J, Suprayudi MA, Wiyoto W, Hazanah RF, Lenggara GS, Sulistiani R, Alkahfi M, Zairin M. 2016. Biofloc technology application in African catfish fingerling production: The effects on the reproductive performance of broodstock and the quality of eggs and larvae. Aquaculture 464: 349-356

Di Falco F, Cammarata M, Vizzini A. 2017. Molecular characterisation, evolution and expression analysis of g-type lysozymes in Ciona intestinalis. Developmental and Comparative Immunology 67: 457-463.

Fauji H, Budiardi T, Ekasari J. 2018. Growth performance and robustness of African catfish Clarias gariepinus (Burchell) in biofloc-based nursery production with different stocking densities. Aquaculture Research 49: 13391346.

Gou C, Wang J, Wang Y, Dong W, Shan X, Lou Y, Gao Y. 2018. Hericium caput-medusae
(Bull.:Fr.) Pers. polysaccharide enhance innate immune response, immune-related genes expression and disease resistance against Aeromonas hydrophila in grass carp Ctenopharyngodon idella. Fish and Shellfish Immunology 72: 604-610.

Liu QN, Xin ZZ, Zhang DZ, Jiang SH, Chai XY, Li CF, Zhou CL, Tang BP. 2016. Molecular identification and expression analysis of a goose-type lysozyme (LysG) gene in yellow catfish Pelteobagrus fulvidraco. Fish and Shellfish Immunology 58: 423-428.

Livak KJ, Schmittgen TD. 2001. Analysis of relative gene expression data using real-time quantitative PCR and the 2- $\Delta \Delta C$ T method. Methods. 25:402-408

Magnadóttir B. 2006. Innate immunity of fish (overview). Fish and Shellfish Immunology 20: 137-151.

Pridgeon JW, Klesius PH, Dominowski PJ, Yancey RJ, Kievit MS. 2013. Chicken-type lysozyme in channel catfish: Expression analysis, lysozyme activity, and efficacy as immunostimulant against Aeromonas hydrophila infection. Fish and Shellfish Immunology 35: 680-688.

Saurabh S, Sahoo PK. 2008. Lysozyme: An important defence molecule of fish innate immune system. Aquaculture Research 39: 223-239.

Shoko AP, Limbu SM, Mgaya YD. 2016. Effect of stocking density on growth performance, survival, production, and financial benefits of African sharp tooth catfish Clarias gariepinus monoculture in earthen ponds. Journal of Applied Aquaculture 28: 220-234.

Wang R, Feng J, Li C, Liu S, Zhang Y, Liu Z. 2013. Four lysozymes (one c-type and three g-type) in catfish are drastically but differentially induced after bacterial infection. Fish Shellfish and Immunology 35: 136-145.

Wang M, Zhao X, Kong X, Wang L, Jiao D, Zhang H. 2016. Molecular characterization and expressing analysis of the c-type and g-type lysozymes in Qihecrucian carp Carassius auratus. Fish and Shellfish Immunology 52: 210-220.

Wohlkönig A, Huet J, Looze Y, Wintjens R. 2010. Structural relationships in the lysozyme superfamily: Significant evidence for glycoside hydrolase signature motifs. PLoS One 5: 1-10.

Yarahmadi P, Miandare HK, Fayaz S, Caipang CMA. 2016. Increased stocking density causes changes in expression of selected stressand immune-related genes, humoral innate immune parameters and stress responses of 
rainbow trout Oncorhynchus mykiss. Fish and Shellfish Immunology 48: 43-53.

Ye X, Zhang L, Tian Y, Tan A, Bai J, Li S. 2010. Identification and expression analysis of the g-type and c-type lysozymes in grass carp Ctenopharyngodon idellus. Developmental and Comparative Immunology 34: 501-509.

Zhang S, Xu Q, Boscari E, Du H, Qi Z, Li Y, Huang J, Di J, Yue H, Li C, Congiu L, Wei
Q. 2018. Characterization and expression analysis of g- and c-type lysozymes in Dabry's sturgeon Acipenser dabryanus. Fish and Shellfish Immunology 76: 260-265.

Zhou T, Yuan Z, Tan S, Jin Y, Yang Y, Shi H, Wang W, Niu D, Gao L, Jiang W, Gao D, Liu Z. 2018. A review of molecular responses of catfish to bacterial diseases and abiotic stresses. Frontier in Physiology 9: 1-16. 